$$
\cos =-841157-2
$$

UCRL- -90675

1)E35 0022.47

\title{
Corrosion Behavior of Carbon Steels Under Tuff Repository Environmental Conditions
}

\author{
R. Daniel McCrlyht \\ Haskell Weiss
}

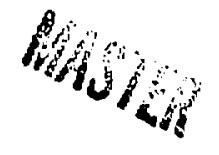

\author{
Materials Research Society \\ 1984 Annual Meeting \\ Boston, MASS \\ November 26-30, 1984
}

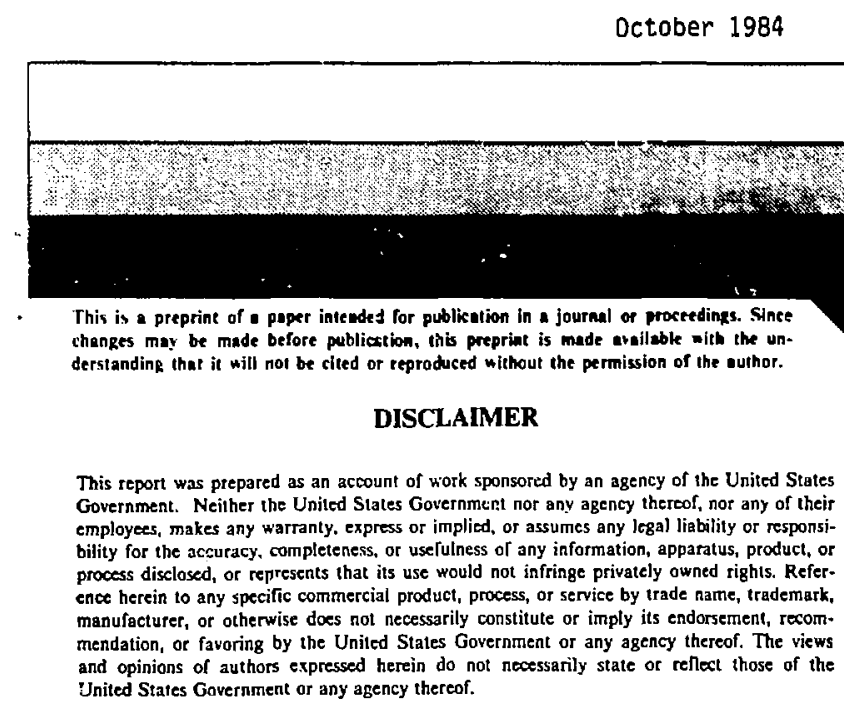

This report was prepared as an account of work sponsored by an agency of the United States Government. Neither the United Stales Government nor any agency thereof, nor any of their employees, makes any warranty. express or implied, or assumes any legal liability or responsjbility for the accuracy, completeness, or uselulness of any information, apparatus, product, or process disclosed, or represents that its use would not infringe privately owned rights. Reference herein to any specific commercial product, process, or service by trade name, trademark, manufacturer, or otherwise does not necessarily constitute or imply its endorsement, recom* mendation, or favoring by the United States Government or any agency thereof. The views United States Government or any agency thereof. 
CORROSION BEHAYIOR OF CARBUN STEELS

UHOER TUFF REPOSITORY ENVIRONMENTAL CONOITIONS

R. DANIEL MCCRIGHT* AND H. WEISS*

* Lawrence Livermore National Laboratory, P.0. Box 808, L-206, Livermore, CA 94550

ABSTRACT

Carbon steels may be used for borehole iners in a potential high-level nuclear waste repository in tuff in Mevada. Borehole liners are needed to facilitate emplacement of the waste packages and to facilitate retrieval of the packages, if required. Corrosion rates of low carbon structural steels AIS1 1020 and ASTM A-36 were determined in J-13 well water and in salurated steam at $100^{\circ} \mathrm{C}$. Tests were conducted in airusparged $\mathrm{J}-13$ water to attain more oxidizing conditions representative of irradiated aqueous environments. A limited number of irradiation corrosion and stress corrosion tests were performed. Chromium-nolybdenum alloy steels an: cast irons were also tested. These materials showed lower general corrosion but. were susceptible to stress corrosion cracking when welded.

INTRUDUCTION

This pader is concerned with the corrosion behavior of caroon steals and other ferrous metals under environmental conditions representative of a hiqn-level waste repository in tuff. Lawrence Livermore National Laboratory (LLNL) is responsiole for high-level nuclear waste package development as part of the ivevada Nuclear waste Storage Investigations (iwwsI) Project. Tris project is Dart of the Department of Enerqy's Civilian Radioactive Waste Management (CRAM) Program, and is investigating the suitabilit.y of tuffaceous rocks at Yucca Mountain in Nye County, Nevada for high-level nuclear waste disposal. The waste package effort at LLiNL is developing multi-oarriered cachages for safe, permanent disposal in a repository such as the one being considered at Yucca Mountain.

While the NiwSI project focuses on austenitic stainless steel as the containment materials for the conceptual design of high-level nuclear waste packages, carbon steel is of interest as the principal candidate material for borenole liners. Selection of candidate materials for the waste package canister and for borehole liners nave beer, previously discussed [1]. The borenole liner is needed to facilitate emplacement of the waste package, and if required, to facilitate the retrievability of the waste package. Haste Dackanes may be emplaced horizontally or vertically in tire repository. In horizontal emplacement designs, multiple waste packages units are spaced along a horizontally mines horehole between parallel drifts. Horizontal borehole lengths of several hundred feet are proposed. Other repository designs call for vertical emplacement of single waste packages in boreholes mined along a drift floor. Vertical boreholes would be lined for the top several feet. Borehole liner thicknesses on the order of $1.25 \mathrm{~cm}$ are under consideration for both the horizontal and vertical emplacement conceptual designs. The retrievability period is 50 years after package emplacement. Therefore, the integrity of the liner material during this 50 -year period is the reason for this investigation of corrosion rates and corrosion attack modes.

Work parformed under the auspices of the U.S. Uepartment of Energy by the Lawrence Livermore National Laboratory under contract number W-7405-ENG.48. 


\section{LINER ENYIRONMENT}

The reference horizon for a repository proposed for Yucca Mountain is about 150 meters ajove the static water level. Heat generated fron the :waste packages after emplacement converts moisture in the near-package environment to steam. Air and steam are the dominant environmental species during the retrievability period. Episodic intrusion of water into the package environment could occur through downward percolation of precipitation along rock fractures. The low annual precipitation in the Nevada desert should minimize the amount of possiole water intrusion. Further, fractures in the rock below the repositcry should permit drainage from the gackage environnent and minimize the time during which the borehole liner surface is in contact with an aqueous phase. A thermal analysis of several different waste package designs in bath horizontal and vertical emplacement arrangements is available [2].

Because the corrosinn rate of carbon steels is highest under wet conditions, the experimental program emphasizes these conditions since they are more limiting in establisning the minimum service length for a qiven grade of steel. As alternative materials to the carbon steel, different grades of cast irons and chromium-molybdenum alloy steels were tested; these materials often snow greater corrosion resistance than carbon steels in aqueous environments, particularly when the environment is oxidizing. Representative water in the repository location is oxidizing. Water from near-by $\mathrm{J}-13$ well is considered representative of vadose water which has percolated through the welded tuff layers in Yucca Mountain and has been conditioned oy contact with this rock. The principal minerals present in the welded tuff layers are quartz, cristoballite, and alkali feldspar.

The corrosion tests reported in this paper were conducted in $\mathrm{J}-13$ well water and, in some cases, in the vapor phase above this water. With regard to the corrosion behavior of the different metals tested, the significant cnemical species present in $\mathrm{J}-1 \hat{j}$ well water are: dissolved oxygen (5-6 ppm); nitrate inn (5-10 ppm); chinride ion $(6-3 \mathrm{ppm})$; fluoride ion $(c-3 \mathrm{ppm})$; bicarbonate ion (110-130 ppm); sulfate ion (20-30 pDm); and sodium iun (40-50 $p p m)$. The pH of tne well water is between 7.1 and 7.5 .

\section{OUTLINE OF CORROSION TEST PROGRAM}

In addition to the general corrosion rates of different candidate borenole liner miterials, the rssistance of these materials to localized and stress-assisted forms of corrosion is also an issue as these forms of corrosion could drastically shorten the service life of the liner. A severely pitted or cracked liner could hinder retrievability of the nuclear waste package.

The data reported in this paper were obtained aver an approximate two-year period. When some of the tests were started, different conceptual designs were betig pursued for the waste package and liner. For instance, at one point a self-shielded canister concept was pursued in which the nuclear wastu would be contained in a thick cast iron canister (on the order of $30 \mathrm{~cm}$ thick) [3]. The present conceptual designs consider a much thinner canister section (on the order of $1 \mathrm{~cm}$ thick) of a more corrosion resistant austenitic stainlass steel. Carbon steel or other iron-base material would be used as a Dorehole liner around the stainless steel canister. Some of the materials (for example, gray cast iron) whose corrosion resistance was investigated as possible self ushielded canister materials would probably not be suitable for fabricating long borehole liners. However, all of the available test results are reported here, because the effects of the different alloying constituents are instructive in understanding the corrosion behavior of this general class of materials. 
Five different tests are discussed in this report: 1 . A weight loss test to determine the general and localized corrosion rates of carbon steel and other Fe-base materials in $\mathrm{J}-13$ water at different temperatures. The $\mathrm{J}-13$ water was "conditioned" by contact with crushed tuff rock and air sparged to saturate the water with oxygen. 2. An electrochemical polarization test of the same alloys as the above to determine the corrosion potentials and currents as a function of temperature. 3. A general and localized corrosion test of unstressed soecimens of carbon steels and other $\mathrm{Fe}-0$ ase materials exposed to $\mathrm{J}-13$ water and saturated steam at $100^{\circ} \mathrm{C}$. The purpose of this experiment was to discern the differences in corrosion rates and corrosion at t.ack modes in the two different phases. 4. A bent-beam stress corrosion susceptibility test of welded specimens if 1020 carbon steel, nodular cast iron, and $9 \mathrm{Cr}-1$ Mo alloy steel in $90^{\circ} \mathrm{C} \mathrm{J}-13$ water. Comparison between the stress corrosion susceptioilities of tne welded zone, heat-affected zone and base metal is possible with this particular stress confiquration. 5. Corrosion tests of specimens exposed to irradiated $\mathrm{J}-13$ water in a gamma radiation facility were performed to determine the effect of radiation on corrosion rates.

\section{MATERIALS TESIED}

The actual chemical analyses of the different materials tested are presented in iables I and II.

Tabie I Composition of Coudons Used in Weignt Loss Corrosion Tests

\begin{tabular}{|c|c|c|c|c|c|}
\hline & Gray Cast Iron & A-36 & 1020 & $21+\mathrm{Cr}-1 \mathrm{Mo}$ & $9 \mathrm{Cr}-1 \mathrm{MO}$ \\
\hline Si & 2.68 & 0.03 & -- & 0,27 & 0.71 \\
\hline .40 & -- & -. & -- & 0.94 & 0.96 \\
\hline $\mathrm{Fe}$ & bal & Dal & bal & bal & bal \\
\hline $\mathrm{Cr}$ & $\ldots$ & $=$ & $\ldots$ & 2.36 & 8.27 \\
\hline$i$ & 3.26 & 0.22 & 0.18 & 0.12 & 0.13 \\
\hline$Y_{n}$ & 0.72 & 0.46 & 0.35 & 0.56 & 0.48 \\
\hline P & 0.038 & 0.008 & 0.040 & 0.016 & - \\
\hline 5 & 0.053 & 0.003 & 0.025 & 0.012 & 0.010 \\
\hline
\end{tabular}

Table II Composition of Weld Plate and Weld Rod Used to Faoricate Bent Beam Stress Corrosion Soecimens

\begin{tabular}{|c|c|c|c|c|c|c|}
\hline & $\begin{array}{r}1020 \\
\text { Plate } \\
\end{array}$ & $\begin{array}{l}\text { E7018 } \\
\text { Rod }\end{array}$ & $\begin{array}{l}9 \mathrm{Cr}-1 \mathrm{Mo} \\
\text { Plate }\end{array}$ & $\begin{array}{l}502-18 \\
\text { Rod }\end{array}$ & $\begin{array}{l}\text { Nod.Fe } \\
\text { Plate }\end{array}$ & $\begin{array}{l}\text { Ni i-Rod } \\
\text { Rod }\end{array}$ \\
\hline Si & 0.08 & 0.40 & 0.71 & 0.05 & 2.98 & 1.27 \\
\hline$N i$ & 0.05 & 0.03 & $0.05 ?$ & 0.08 & 0.25 & 59.48 \\
\hline $\mathrm{Cu}$ & 0.03 & $=$ & 0.11 & - & 0.05 & 2.95 \\
\hline Mo & 0.09 & 0.01 & 0.96 & 0.62 & 0.01 & -. \\
\hline $\mathrm{Fe}$ & bal & Dal & bal & bal & bal & ba? \\
\hline $\mathrm{Cr}$ & 0.07 & $<0.01$ & 8.27 & 4.96 & 0.01 & $0: 10$ \\
\hline A) & 0.03 & -. & 0.009 & - & $\ldots$ & - \\
\hline$\hat{\imath}$ & 0.22 & 0.03 & 0.13 & 0.06 & 3.30 & 0.78 \\
\hline inn & 0.50 & 0.67 & 0.48 & 0.44 & 0.17 & 0.81 \\
\hline$p$ & 0.027 & 0.014 & -. & 0.020 & 0.027 & 0.007 \\
\hline 5 & -- & 0.015 & 0.010 & 0.019 & 0.011 & 0.002 \\
\hline
\end{tabular}

Blank space means not determined. 


\section{CORROSIUN TEST RESULTS}

\section{Weignt Loss Tests in J-13 Water}

The weight loss experienced by the coupons of carbon steel, cast iron, or alloy steel was determined by AST, $G-1$ and $G-31$ test procedures at periodtc intervals. The coupons were also examined for any evidence of localized attack, and the depth of localized attack was determined by a focusing microscope (ASTM G-46). Slotted Teflon washers were used as fasteners ta hold the coupons to fiderglass mounting sticks. The slatted washers intentionally ereated a creviced area on the coupon so that localized corrosion attack would preferentially occur in this area. Nearly all of the materials tested showed some preferential crevice attack; many also showed some lacalized attack on the "bold" area of the coupon as. well. Attack on the bold area outside the creviced area is termed "pitting attack" in this discussion. The "pitting" attack rate and the "crevice" attack rate are expressed on an annualized basis to make a direct comparison of the localized attack to the qeneral attack. The ratio of pitting corrosion rate to general corrosion rate and the crevice corrosion rate to the general corrosion rate are called the "pit factor" ant "crevice factor", respectively.

Table III summarizes the results from coupon tests of carbon steel, dlloy steel and Cas: iron in 50-100 ${ }^{\circ} \mathrm{C} \mathrm{J}-13$ water. These solutions were intentionally air-soarged to create highly aric conditions and estaolish a high but cradible corrosion penetration rate for the different materials. These resuits represent the average of tinree replicate coupons for each alloy at each test temperature. The coupons were exposed for 1500 hours. 1020 caroon steel showed consistently the highest corrosion rates of the materials tested, wrile the $9 \mathrm{Cr}-1$ Mo allay steel exhidited corrosion rates which were consiaerialy less than those for the other alloys. Maximum corrosion rates were attained at $7 \mathrm{C}$ or $60^{\circ} \mathrm{C}$ with the rate decreasing at higher temperatures because of trie decrease in oxygen solubility in the water. Localized corrosion observations on these exposed coupons are summarized in Tabie lll.

The results indicate that while the $9 \mathrm{Cr}-1$ Mo alloy steel snows a low general currosion rate in the $J-i 3$ water, the alloy is moderately susceptible to localized attack particularly in crevices. The localized susceptioilitis is hignest at 70 and $80^{\circ} \mathrm{C}$ and lawest at $100^{\circ} \mathrm{C}$. The lower localized corrosion susceptisility may be due to the lower solubility of oxygen at the higher temperatures and smaller differences between the concentration of $a_{2}$ in the crevice and that on the nold surface. This alloy steel apdears to take on the characteristics of a "stainiess steel" in the $\mathrm{J}-13$ water with respect to its general corrosion, but the amount of alloying $C r$ and Mo is insufficient to confer a high deoree of localized corrosion resistance. The 02 contents were determined in the water at the different temperatures: $50^{\circ} \mathrm{C}(6.65 \mathrm{ppm}$ $02)$; $70^{\circ} \mathrm{C}(5.60 \mathrm{p} \mathrm{pm}) ; 80^{\circ} \mathrm{C}(4.50 \mathrm{ppm}) ; 90^{\circ} \mathrm{C}(3.30 \mathrm{ppm}) ;$ and $100^{\circ} \mathrm{C}(2.25 \mathrm{ppm})$.

\section{Electrocnemical Polarization Tests}

As ar analogue to the weight loss coupon tests, the corrosion rates of the different steels were determined by electrochemical methods. The linear colarization resistance method was used to determine the corrosion currents [4]. These results are summarized in Table IV. These results were obtained from sinqle specimens of ach material. Corrosion potentials were measured against a saturated calomel electrode (SCE). The corrosion potentials for tne $9 \mathrm{Cr}-1 \mathrm{Ma}$ alloy steel are substantially more anodic than those of the other materials tested. This observation is in agreement with the nearly stainiess character of this alloy. The corrosion rates given in Table IV are in goad agreement with the rates determined from this wight :oss (Tade III). 
Table III General and Localized Corrosion Rates of Stee is in J-13 Water at Different Temperatures

\begin{tabular}{|c|c|c|c|c|c|}
\hline $\begin{array}{l}\text { Temp. } \\
\left({ }^{\circ} \mathrm{C}\right)\end{array}$ & $\begin{array}{c}\text { General } \\
\text { Corrosion } \\
\text { Sate (im/yr) }\end{array}$ & $\begin{array}{l}\text { Pitting } \\
\text { Corrosion } \\
\text { Rate ( }-\pi / y r)\end{array}$ & $\begin{array}{l}\text { Pitting } \\
\text { Factor } \\
\text { I }\end{array}$ & $\begin{array}{c}\text { Crevice } \\
\text { Corrosion } \\
\text { Rate (um,yr) } \\
\end{array}$ & $\begin{array}{l}\text { Crevice } \\
\text { Factor } \\
\end{array}$ \\
\hline $\begin{array}{l}50 \\
70 \\
80 \\
90 \\
100\end{array}$ & $\begin{array}{l}401 \\
505 \\
531 \\
414 \\
320\end{array}$ & $\begin{array}{rl}380 & 1020 \mathrm{Ca} \\
1018 & \\
465 & \\
1046 & \\
1013 & \\
& \text { Gray C }\end{array}$ & $\begin{array}{l}\text { arbon Ste } \\
0.95 \\
2.02 \\
0.88 \\
2.52 \\
3.18 \\
\text { Cast Iron }\end{array}$ & $\begin{array}{l}413 \\
359 \\
472 \\
563 \\
635\end{array}$ & $\begin{array}{l}1.03 \\
0.71 \\
0.89 \\
1.36 \\
1.93\end{array}$ \\
\hline $\begin{array}{l}50 \\
70 \\
80 \\
90 \\
100\end{array}$ & $\begin{array}{l}359 \\
422 \\
357 \\
323 \\
318\end{array}$ & $\begin{array}{r}203 \\
392 \\
79.6 \\
27.9 \\
0.0 \\
-1 / 4 \mathrm{Cr}-1 \mathrm{Mo}\end{array}$ & $\begin{array}{l}0.57 \\
0.94 \\
0.22 \\
0.09 \\
0.00 \\
0 \text { Alloy S }\end{array}$ & $\begin{array}{c}98.2 \\
138 \\
305 \\
14.6 \\
232 \\
232 \\
1 \text { Steel }\end{array}$ & $\begin{array}{l}0.42 \\
0.43 \\
0.35 \\
0.05 \\
0.69\end{array}$ \\
\hline $\begin{array}{l}50 \\
70 \\
80 \\
90 \\
130\end{array}$ & $\begin{array}{l}316 \\
469 \\
376 \\
370 \\
278\end{array}$ & $\begin{array}{l}649 \\
1449 \\
1089 \\
868 \\
1352 \\
9 \mathrm{Cr}-1 \mathrm{M}\end{array}$ & $\begin{array}{l}2.07 \\
3.07 \\
2.30 \\
1.83 \\
4.87 \\
10.4110 y\end{array}$ & $\begin{array}{l}946 \\
1100 \\
1415 \\
800 \\
781 \\
1\end{array}$ & $\begin{array}{l}2.97 \\
2.33 \\
3.63 \\
2.17 \\
4.50\end{array}$ \\
\hline $\begin{array}{l}50 \\
70 \\
7 \\
90 \\
100\end{array}$ & $\begin{array}{r}21.2 \\
21.2 \\
14.1 \\
8.3 \\
6.3\end{array}$ & $\begin{array}{c}4 \overline{2.3} \\
152 \\
246 \\
0.0 \\
0.0\end{array}$ & $\begin{array}{l}1.83 \\
7.47 \\
17.4 \\
0.00 \\
0.00\end{array}$ & $\begin{array}{r}202 \\
450 \\
319 \\
84.7 \\
33.0\end{array}$ & $\begin{array}{r}14.6 \\
22.5 \\
23.1 \\
10.1 \\
8.10\end{array}$ \\
\hline
\end{tabular}

Iasle IV Corrosion Potentials and Currents of Steels in J-13 Nater.

\begin{tabular}{|c|c|c|c|c|}
\hline Material & $\begin{array}{l}\text { Temp. } \\
\left({ }^{\circ} \mathrm{C}\right)\end{array}$ & $\begin{array}{c}\text { Corrosion } \\
\text { Potential } \\
\text { (mV. v5 SCE) } \\
\end{array}$ & $\begin{array}{l}\text { Corrosion } \\
\text { Curreat } \\
\left.\text { (uA/Cm }{ }^{2}\right)\end{array}$ & $\begin{array}{l}\text { Corrosion } \\
\text { Rate } \\
\text { (um/yr) }\end{array}$ \\
\hline $\begin{array}{l}\text { Gray Cast } \\
\text { Iron }\end{array}$ & $\begin{array}{l}50 \\
70 \\
30 \\
90\end{array}$ & $\begin{array}{l}-593 \\
-582 \\
-595 \\
-594\end{array}$ & $\begin{array}{l}32.8 \\
21.0 \\
28.5 \\
40.4\end{array}$ & $\begin{array}{l}366 \\
233 \\
318 \\
452\end{array}$ \\
\hline 1020 Steel & $\begin{array}{l}50 \\
70 \\
80 \\
90\end{array}$ & $\begin{array}{l}-691 \\
-690 \\
-691 \\
-678\end{array}$ & $\begin{array}{l}81.2 \\
50.1 \\
75.2 \\
67.0\end{array}$ & $\begin{array}{l}856 \\
559 \\
841 \\
749\end{array}$ \\
\hline $\begin{array}{l}21 / 4 \mathrm{Cr}- \\
1 \text { Mo Alloy } \\
\text { Steel }\end{array}$ & $\begin{array}{l}50 \\
70 \\
80 \\
50\end{array}$ & $\begin{array}{l}-600 \\
-380 \\
-508 \\
-363\end{array}$ & $\begin{array}{l}25.5 \\
2.1^{1} \\
10.4 \\
2.1\end{array}$ & $\begin{array}{l}285 \\
22.9 \\
117 \\
22.9\end{array}$ \\
\hline $\begin{array}{l}9 \mathrm{Cr}-\mathrm{I} \text { ito } \\
\text { Alloy Steel }\end{array}$ & $\begin{array}{l}50 \\
70 \\
80 \\
90\end{array}$ & $\begin{array}{l}-318 \\
-381 \\
-380 \\
-335\end{array}$ & $\begin{array}{l}2.4 \\
3.6 \\
4.7 \\
1.8\end{array}$ & $\begin{array}{l}27.9 \\
40.6 \\
53.3 \\
20.3\end{array}$ \\
\hline
\end{tabular}




\section{Corrosion Coupon Tests in Hater and Steam}

Corrosion rates measured after 5000 hours of exposure to boiling $\mathrm{J}-13$ water and to the saturated steam above the water are presented in Table $V$. These tests followed the same procedures as those reported in section 1 (weight loss tests in $3-13$ water). The data in Table $V$ show that the corrosion rates are lower for the metals exposed in the vapor phase than in the liquid.

Table $V$ Corrosion Rates of Steel Coupons Exposed 5000 Hours to $\mathrm{J}-13$ Water and 5 team at $100^{\circ} \mathrm{C}$

\begin{tabular}{ccc} 
Material & $\begin{array}{c}\text { Corrosion Rate in } \\
\text { Water (um/yr) }\end{array}$ & $\begin{array}{c}\text { Corrosion Rate in } \\
\text { Steam (um/yr) }\end{array}$ \\
\cline { 3 - 4 } 1020 Steel & 26.8 & $\frac{12.5}{9-36 \text { Stee) }}$ \\
$9 \mathrm{Cr}-1$ Mo & 30.2 & 9.74 \\
& 0.70 & -0.55 (wt. gain)
\end{tabular}

After 5000 hours, the maxinum localized corrosion rates expressed in $4: \pi / y r$ were: 1020 Steel (262 in the water and 185 in the steam); $A-30$ Steel (152 in water and 159 in steam). Both tne qeneral corrosion penetration rates and the localized corrosion rates decreased with an increase in exposure time. For example: after 3000 hours the general corrosion rate of the 1020 carbon steel was $41.6 \mathrm{um} / \mathrm{yr}$ in the water and $20.3 \mathrm{um} / \mathrm{yr}$ in the steam; while the naximum localized rates were $260 \mathrm{um} / \mathrm{yr}$ in the water and $331 \mathrm{um} / \mathrm{yr}$ in tne steam. These tests are continuing to accumulate longer exposure periods.

\section{Stress Corrosion Test Results}

Specimens were prepared from welded 1/4-inch plates of the ferrous alloys. Tne compositions of the plate and weld rod are given in the olocks in Table II. These are the standard AWS filler materials recommended for these plate materials. The differences in alloy composition between plate and rod should be noted. A Jugroove was machined into the plate stock, and the weld was made in one pass with a $1 / 8$-inch shielded metal electrode. All welding of the 1020 steel was done at amoient temperature, but some of the nodular cast iron and the alloy steel plates were pre-heated to 150 or $200^{\circ} \mathrm{C}$. After welding, the plates were machined to cross sections between 0.060 to 0.125 inch to provide jefect-free weld areas. Nine bent beam specimens were machined from each welded plate. The bent beam specimens were loaded in a four-point fixture and then stressed to $90 \%$ of their respective yield strengths (ASTM G-39).

The stressed specimens were emplaced in $90^{\circ} \mathrm{C} \mathrm{J-13}$ viater and inspected after 500 hours and in 1000-hr increments after that. The first sign of cracking accurred on two specimens of $9 \mathrm{Cr}-1$ Mo which foiled after 3500 hours of testing. Table VI gives a summary of the results from the bent beam specimen tests after 9000 hours of exposure. None of the 1020 carbon steel specimens have failed to date. It is suggested that a hydrogen emorittlement mechanism is responsible for the failures of the nodular cast iron and $\mathrm{Cr}$-Mo alloy steel soecimens. The compositional differences between the base and weld metal create microstructural differences. The fracture morpnology of the cast iron and alloy steel specimens was similar in that both are intergranular and occurred in the weld metal. Galvanic differences between the weld and the base metal deve 00 and the weld acts as a cathode to the base metal. This explanation was confirmed in a laboratory determination of the actual potential on the weld and on the base metal. Further, the weld metal was entirely martensitic; the high internal stress in martensite renders it more susceptible to hydrogen embrittlement. These tests are continuing. 
Table VI Stress Corrosion Test Results on Bent Beam Specimens Exposed to $90^{\circ} \mathrm{C} \mathrm{J}-13$ Water. 9000 Hours of Exposure.

\author{
Nodular Cast Iron \\ $9 \mathrm{Cr}-1$ ito \\ 1020 Stee 1 \\ 1 out of 9 specimens failed \\ 6 out of 9 specimens failed \\ no specimens failed
}

\title{
5. Irradiation Corrosion Tests
}

A limited number of corrosion tests have been performed at $105^{\circ} \mathrm{C}$ in irradiated aerated J-13 water on 1025 wrought steel and on $9 \mathrm{Cr}-1$ Mo alloy steel. Crushed tuff rock was placed in the test vessel so that some specimens were "embedder" in the rock + water "phase". These results are qiven in Table VII. These tests were performed in the gamma radiation facility at Pacific Nortnwest Laboratory. The calculated gamma dose rate was $3 \times 1 \mathrm{ic}^{5} \mathrm{rads} / \mathrm{hr}$. The values given in Taole VII are the averages of 6 or 7 coupors, $n$ each location. The corrosion rates in this irradiated environm it are nigner for both the carbon steel and the alloy steel than in a combarable non-irradiated environment (Table $V$ at $100^{\circ} \mathrm{C}$ ). This increase is undoubtedly due to the production of oxygen, hydrogen peroxide, and other oxidizing species by radiolysis of tne water.

Table VII Corrosion of Steels in Irradiated J-13 Water at $105^{\circ} \mathrm{C}$. Exposure Period of 3 Molilis, Gamma Dose Rate of $3 \times 10^{5} \mathrm{rads} / \mathrm{hr}$.

\begin{tabular}{llr} 
Material & "Phase" & Corrosion \\
\cline { 2 - 3 } lu25 Wrought & Water & 36 \\
Steel & Nater + Rock & 45 \\
$9 \mathrm{Cr}-1$ Ho & Water & 15 \\
& Water + Rock & 21
\end{tabular}

\section{CONCLUSIONS AND FJTURE WORK}

The work indicates that AISI 1020-1025 or ASTM A-36 carbon steel should not suffer excescive corrosion in the tuff repository environmental conditions tested so far. These conditions include $\mathrm{J}-13$ well water in the temperature range $50-100^{\circ} \mathrm{C}$, saturated steam at $100^{\circ} \mathrm{C}$, and irradiated $\mathrm{J}-13$ water at $105^{\circ} \mathrm{C}$. When the solutions are intentionally air sparged, the corrosion rate increases with the increase in oxygen content of the solution. The maximum corrosion rate occurs at $70-80^{\circ} \mathrm{C}$, where the flux of oxygen to the steel surface is maximum. The maximum is determined by the increase in diffusion rate of oxygen with increasing temperature, and the decrease in oxygen solubility with increasing temperature. Carbon steels also appear to be resistant to stress corrosion in the modes so far tested. Some localized corrosion occurs, with the localized corrosion factor usually on the order of 1-3 times the general corrosion rate. The localized (crevice) corrosion rate can be as high as 15 times the general corrosion rate in wet stean conditions. A $1.25 \mathrm{~cm}$ thick borehole liner fabricated from carbon steel could attain a service life of more than 50 years according to projections of these data if continuo - iy wet conditions do not dominate the environment. The anticipated environmental conditions at the Yucca Mountain repository are "dry" because of the low water percolation rate to the repository horizon. The test conditions used her were immersion of specimens in water and exposure to wet steaming condit ...s in order to give an upper limit. Additional testing time is needed to 
substantiate these first results and projections. Possid le galvanic effects between a carbon steel liner and a stainless steel canister needs to be addressed.

While the $9 \mathrm{Cr}-1$ Mo alloy steel exhibits a lower corrosion rate than carbon steel, the nigh susceptibility of this matarial to hydrogen embrittlement (a form of stress corrosion cracking) in the welded condition makes it unsuitable for further consideration. While a post-weld heat treatment could temper the martensite and reduce the susceptibility, this extra operation in the installation of a liner would be impractical and costly. Perhaps, a low-carbon, high-alloy steel could combine the best features of corrosion resistance with better welding characteristics.

\section{REFERENCES}

[1] R. D. McCright, H. Weiss, M. ¿. Juhas, and R. W. Logan, "Selection of Canister Materials for High-Level Nuclear Waste Containment in a Tuff

- Repository", Lawrence Livermore National Laboratory Report UCRL-89988, (November, 1983).

[2] J. N. Hockman and W. C. O'Neal, "Thermal Modeling of Nuclear Waste Package Designs for Disposal in Tuff", Lawrence Livermore National Laboratory Report UCRL-89820 Rev 1, (February, 1984).

[3] "Conceptual Waste Package Designs for Disposal of Nuclear Waste in Tuff", Westinghouse Electric Co. Report AESD-TME-3138, (September, 1982).

[4] S. W. Dean, "Electrochemical Methods of Corrosion Testing", Electrochemical Techniques for Corrosion, pp.52-56, Nat'l Ass'n Corrosion Engineers, Houston, TX (1977). 